\title{
Analysis of hotz plate appliance to the development of maxillary arch growth of patient with cleft lip and palate
}

\section{Edy Machmud}

Departement of Prosthetic

Faculty of Dentistry Hasanuddin University

Makassar, Indonesia

\section{ABSTRACT}

This study was an observational, cross sectional study with purpose to analyze the effect of hotz plate appliance to the development of maxillary arch of patients with cleft lip and palate. Twelve samples with cleft lip andpalate, age under 2 years were recruitedfrom two different hospitals. Six samples used hotz plate appliance were recruited from Rumah Sakit Hasan Sadikin, Bandung while the other six as control didn't use hotz plate appliance were recruited from Rumah Sakit Haji, Makassar. The result showed that minor maxillary arch was similar in size with major maxillary arch of patient with hotz plate appliance, however, patient without hotz plate appliance, showed longer minor maxillary arch than major maxillary arch. It can be concluded from this study that hotz plate appliance had an effect on the palatal development of patient with complete unilateral cleft lip and palate and also prevented the collapse of minor maxillary arch to either anterolateral or anteromedial.

Keywords: Hotz plate appliance, maxillary arch development, cleft lip and palate

\begin{abstract}
ABSTRAK
Penelitian ini adalah penelitian observasi dengan rancangan cross sectional yang bertujuan untuk menganalisis pengaruh penggunaan piranti hotz plate terhadap perkembangan lengkung rahang atas dari pasien dengan celah bibir dan langit-langit - satu sisi.Sampel adalah pasien celah bibir dan langit-langit, berusiadibawah 2 tahun yang menggunakan piranti hotz plate sebanyak 6 orang berasal dari Rumah Sakit Hasan Sadikin Bandung
\end{abstract}


dan 6 orang sampel berasal dari Rumah Sakit Haji Makassar dengan celah bibir dan langit-langit usia dibawah 2 tahun tidak menggunakan piranti hotz plate sebagai kontrol. Hasil penelitian menunjukkan bahwa ukuran lengkung maksila minor bagian anterior sama dengan panjang lengkung maksila mayor pada pasien dengan piranti hotz plate. Namun berbeda pada pasien yang tidak menggunakan piranti hotz plate, ukuran lengkung maksila minor lebih panjang dari lengkung maksila mayor. Simpulan dari penelitian ini adalah piranti hotz plate mempunyai pengaruh terhadap perkembangan langit-langit pasien dengan celah bibir dan langit-langit satu sisi dan mencegah lengkung maksila minor kolaps ke arah anterolateral maupun ke anteromedial.

Kata kunci: Piranti hotz plate, perkembangan lengkung maksila, celah bibir dan langit-langit

Correspondence: Edy Machmud, Department of Prosthodontics, Faculty of Dentistry Hasanuddin University, Jl. KandeaNo.5 Makassar, Indonesia.

\section{INTRODUCTION}

Manifestation of cleft lip and palate of newborn are shown by different face morphology pattern compared with them without cleft lip and palate. This congenital defect causes face asymmetry and deviation of growth pattern from face structure. ${ }^{1}$ A characteristic of complete unilateral cleft lip and palate patients is a separation of lip, alveolar, and palate structure to two portions. The portion with defect is known as the side of cleft and other portion known as the side without cleft. The side without cleft is characterized with more shifting of major maxillary arch away from cleft together with shifting of nose and nasal septum. This shifting is caused by minimal bone support to persist muscle attraction, and the attachment of lip muscle to the base of nose. ${ }^{2}$

Some techniques and methods of application of hotz plate appliances have been developed since 1960, one of them is combined with bone graft. Some investigators disagree with the use of this appliance, however another investigators support the successful treatment with hotz plate appliance. ${ }^{3}$ 
They, who were contrary with application of this appliance stated that the effects of surgical lip restoration can cause modeling action of maxillary arch naturally, match and close each other. They stated that major and minor maxillary arch can move an*d close each other without hotz plate appliance. 4

These contradictions can be solved by research in the centre treatment of cleft lip and palate. Based on the problem above, this study was conducted to investigate the effect of hotz plate appliances to maxillary arch development of infants with cleft lip and palate.

The objectives of this study were to analyze the length of major maxillary arch of complete unilateral cleft lip and palate patient using hotz plate appliance and to compare with them without using the appliance, to analyze the length of anterior minor maxillary arch of complete unilateral cleft lip and palate patient using the hotz plate appliance and to compare with them without using the appliance, to analyze the length of minor maxillary'arch and major maxillary arch of complete unilateral cleft lip and palate patient using hotz plate appliance and to compare with them without using the appliance, and to analyze the length of minor maxillary arch and major maxillary arch without using hotz plate appliance.

\section{MATERIALS AND METHOD}

Research materials which were used in this study were hydrophilic vinyl polysiloxane impression material (Exaflex), individual custom tray for children, and measurement appliance is Mitutoyo Caliper's from Japan with $0.02 \mathrm{~mm}$ of level of accuracy.

The processes of this study were study model of maxillary arch were performed to determine point of landmark, as a reference point to analyze the maxilla. The measurement is according to Otto Kriens method. ${ }^{6}$

Reference point of maxilla model: A-C: Major length of anterior region Linear length of major maxillary arch is placed on the cleft side, measured from canine cusp in the major maxillary arch to interdental of central " incisor.

A-C: Minor length of anterior region Linear length of minor maxillary arch place on the cleft side, measured from canine cusp in minor arch to interdental of central incisor. S-S': Width of anterior space/gap Linear length of anterior cleft, measured from tip of major alveolar arch and tip of 
minor alveolar arch. $C-C$ Canine point on the top of anine cusp. If no canine exists, the intersection point between frenulum labialis lateral and top of alveolar ridge can be used.

Point of tuberosity or intersection point of maxillary tuberosity and top of posterior alveolar ridge.

Working cast was taken from arch casting of complete unilateral cleft lip and palate patient in surgical room, immediately before performing surgical palate coverage. Impression material used is a hydrophilic- vinylpolysiloxane impression material (Exaflex) with high accuracy, ideal flow rate and viscocities and hardened quickly. The cast was poured with hard gypsum as a working cast. Measurement of linear length was performed one time using Mitutoyo Caliper's Japan with 0.02 level of accuracy. The measurement of working cast was focused to major and minor maxillary arch length stake at reference point from pentagonal feature, A as a point of top. C-C as a roof of building, and T-T as bases of building. AC linear length measurement represents anterior portion major segment and minor measurement is AC measure (cleft side) that AS, SS' and $S^{\prime} C$. According to normal jaw study model that have pentagonal building and TT' as a base of building. For easier, anterior portion (non cleft side) is called non cleft AC and portion anterior minor arch (cleft side) is called cleft AC. ${ }^{6}$

\section{RESULT}

Mean value of the length of major maxillary arch using hotz plate appliance, showed in table 1 . Statistical result indicated that there was no significantly difference $(p<0.05)$ between the length of major maxillary arch with hotz plate appliance and major maxillary arch length without an appliance 
Table 1. Major maxillary arch length patient with hotz : plate appliance and patient without an appliance

\begin{tabular}{lccc}
\hline \multicolumn{4}{c}{ Mean \pm Standar Deviation (MM } \\
Variabel & With hotz plate & Without appliance & Significance $(p<0.05)$ \\
\hline Major Maxillary Arch & $16.293 \pm 1.8479$ & $16.776 \pm 0.759$ & $0.313^{*}$ \\
\hline Note: $\mathrm{T}_{\text {coum }}=1.024, \mathrm{~T}_{\text {ubk }}=1.70$, Non significance & &
\end{tabular}

Table 2. Minor maxillary arch length of application hotz plate appliance appliance and without application

\begin{tabular}{lccc}
\hline \multicolumn{3}{c}{ Mean \pm Standar Deviation (MM } \\
Variabel & With hotz plate & Without appliance & Significance $(\mathrm{p}<0.05)$ \\
\hline Major Maxillary Arch & $15.252 \pm 1.614$ & $19.010 \pm 3.605$ & $0.000^{\star \star \star}$ \\
\hline Note: $\mathrm{T}_{\text {coum }}=4.037, \mathrm{~T}_{\text {lablc }}=1.70,{ }^{* \star *}$ More significance &
\end{tabular}

Table 3. Minor maxillary arch length and major maxillary arch length of application hotz plate appliance.

\begin{tabular}{|c|c|c|c|}
\hline \multicolumn{4}{|c|}{ Mean \pm Standar Deviation (MM } \\
\hline Variabel & With hotz plate & Without appliance & Significance $(p<0.05)$ \\
\hline $\begin{array}{l}\text { Aplication hotz plate } \\
\text { appliance }\end{array}$ & $16.293 \pm 1.848$ & $15.252 \pm 1.614$ & $0.078^{\star \star \star}$ \\
\hline
\end{tabular}

Note: $\mathrm{T}_{\text {comn }}=1.872, \mathrm{~T}_{\text {ublc }}=1.74,{ }^{* \star *}$ Non significant

Table 4. Minor maxi appliance illaryarch length of application hotz plate appliance and without application an

\begin{tabular}{lccc}
\hline \multicolumn{4}{c}{ Mean \pm Standar Deviation (MM } \\
Variabel & With hotz plate & Without appliance & Significance $(\mathrm{p}<0.05)$ \\
\hline Without aplication & $16.776 \pm 0.759$ & $19.010 \pm 3.605$ & $0.026^{* * *}$ \\
hotz plate appliance & & \\
\hline Note: $T_{\text {comn }}=1.442, \mathrm{~T}_{\text {ublc }}=1.74,{ }^{* *}$ significant \\
Mean value of minor maxillary & between minor maxillary arch length of \\
arch length of application hotz plate & application hotz plate appliance and \\
appliance, showed in table 2. & without application an appliance. \\
Statistical result indicated that there is & Mean value of minor maxillary arch \\
significantly difference $\quad(p<0.05)$ & length and major maxillary arch length
\end{tabular}


of application hotz plate appliance, showed in table 3. Statistical result indicated that there is no significantly difference $(p<0.05)$ between minor maxillary arch length and major maxillary arch length application hotz plate appliance.

Mean value minor maxillary arch length and major maxillary arch length, showed in table 4. Statistical result indicated that there is significantly difference $(p<0.05)$ between length of minor maxillary arch and length of major maxillary arch without application hotz plate appliance.

\section{DISCUSSION}

To describe the shape/type of anterior maxillary arch is by measuring the length of major and minor maxillary arch of patients with and without hotz plate appliance pre operation orthopaedic, is one of the way to observe the effect of using hotz plate appliance to the cleft lip and palate. Some studies related to the use hotz plate appliance have been conducted two dimensional measurement of maxilla cast model,' and linear curve measurement by the trigonometric measurement technique, which measure a palate surface angle and maxillary arch length radius circle. ${ }^{7}$
The most valid measurement is the three dimensional technique, which was developed to analyze maxillary palate and arch length configuration of the cleft lip and palate patients. Three dimensional analyze is carried out longitudinally with a serial cast model of the cleft lip and palate patients with age range from 3,6 months and so forth. It is expected to show the development of palate more accurately including palate configuration of cleft lip and palate patients with hotz plate appliance." The effectiveness of the using hotz plate appliance by Winters, beside to observed the maj.or and minor maxillary arch length, it is used to observe the presence of cross bite and the direction of incisive lateral development.

The result showed that there is difference of minor arch length between patients with and without an appliance. Compared with the patients using hotz plate appliance, the minor maxillary arch length of without hotz plate appliance is significantly different from minor maxillary arch length of the patients with the appliances (15.252 $1.614 \mathrm{~mm}$ ).

The minor maxillary arch length of the cleft lip and palate patients without hotz plate appliance had a 
different size with major maxillary arch length (19.010 $3.605 \mathrm{~mm}$ ).

The observation of minor maxillary arch showed position, arch curvature, and cleft distance to the major maxillary arch, caused a significant difference from minor maxillary arch length which was longerthan major maxillary arch length.

The measurement of major maxillary arch length in this study, both patient with or without hotz plate appliance, showed that there was no significantly difference. Major maxillary arch of the cleft lip and palate patients, was a part of maxillary structure that had no abnormality or had no cleft. Thus, major maxillary arch represented maxillary structural that had no developmental abnormalities. In fact that study measurement result was no differences of major maxillary arch length size between the patients with or without an appliance. This was according to Honda and Suzuki,"' and Mishima et al" studies, those used anterior maxillary arch length size to the age group when the cleft palate reconstruction was taken place. In fact, this study showed no differences of palatal anteroposterior size, both in patients with or without hotz plate appliance.
This study compared the cleft lip and palate patient with and without hotz plate appliance, and found that there was a significant difference of the length of minor maxillary arch for both group. The length of minor maxillary arch without hotz plate appliance (19.010 $3.605 \mathrm{~mm})$ was different with the length of minor maxillary arch with hotz plate appliance (15.252 $1.614 \mathrm{~mm}$ ).

The patients with hotz plate appliance, had no difference in length between minor maxillary arch and major maxillary arch, because of an appliance influenced the minor maxillary arch slided and approached the major maxillary arch, thus it had been repositioned and matched, symmetry and had a some length.

Mishima et al" studied the effectiveness of Hotz plate in children with cleft lip and palate until they had a labioplasty surgery. His study compared cleft lip and palate without hotz plate as a control.

The result showed that patients with Hotz plate leaded to prevent a maxillary segmental slide to lateral, against to the attractive force of orbicularis oris muscles. Without Hotz plate, maxillary segmental slide to laterally and anteriorly. This was according to Mishima, between Hotz 
plate group and without Hotz plate group in the 18 month group, with cleft size of minor maxillary arch and major maxillary arch of Hotz plate user, smaller than patient without Hotz. In principle, the using of Hotz plate leaded to prevent a maxillary segmental slides to laterally, against the attractive force if orbicularis oris muscle and able to narrowing the size of cleft."

Hotz plate has a significant role to prevent the segment slide laterally and collapse caused by the force of orbicularis oris muscle after labioplasty. The cleft lip and palate patient with this device leaded to prevent the maxillary segment collapse to medially caused by the force of lip muscle and that influence. Still remains until the age of 4 year Huddart studied the patients with cleft lip and plate with hotz plate appliance before surgery. This devices act as feeding aid decrease the size of the cleft wide and creates the lip muscles more relax especially when the cleft lip reconstruction was taken place. Although Ross was not disagreed with this statement, he considered that hotz plate appliance used for baby, does not show longitudinal effect to the face development. $^{5}$
It was shown that major and minor maxillary arch were getting closed. The use of hotz plate to the infants with cleft lip and palate is combined with external elastic strapping. The use of a wire as anchorage to extra-oral and adjacent to the infant cheek, prevents the devices to be swallowed.

In the longitudinal study of patients with cleft lip and palate at one side, it was found that development potential was faster in minor arch than the major arch in first two years after birth. ${ }^{8}$ Prozansky $^{12}$ showed that the phenomenon of development growth of palate both in hard and soft tissues had a development level that faster and had ability to achieve the development process after reconstruction. ${ }^{1}$

Although there was an interval time and be delayed in developmental process, after surgery, the development will delay. The delayed maxillary growti was temporary after the surgery, and will accelerate to achieve a normal arch.

\section{CONCLUSION}

From this study, it was concluded that the application of hotz plate appliance before surgery had an effect to the anterior minor maxillary arch symmetry. On patients without an 
appliance, anterior minor maxillary arch was not symmetry and collapsed into the anterolateral and anteromedial direction.

\section{REFERENCES}

1. Dahl E. Craniofacial morphology in congenital cleft lip and palate. Acta Odontol J 1981;33:92-4.

2. Mazaheri M, Athannasiou AE, Long RE. Evaluation of maxillary dental arch form in unilateral cleft lip and palate from one month to four years cleft palate. $J$ Craniofacial 1993; 30: 90-3.

3. Huddart AG. Presurgical orthopedic treatment in children with unilateral cleft palate. J Cleft Palate. 1979;20:897-904.

4. Skoog T. The use of periosteal flap in the repair of cleft lip and palate on the primary palate. J Cleft Palate 1974; 2: 332-9.

5. Ross RB. Treatment variable affecting facial growth in complete unilateral cleft lip and palate. J Cleft Palate 1988; 24-5.

6. Kriens $O$. Anatomy of the cleft palate primary surgical treatment of cleft palate. Philadelphia: WB. Saunders Co.; 1974.
7. Prasad. Quantitative 3D maxillary arch evaluation of two different infant managements for unilateral cleft lip and palate. J Cleft Palate Craniofac 1999;37:562-70.

8. Berkowitz S. Stereophotogrammetric analysis of cast of normal and abnormal palate. Philadelphia: WB. Saunders Co.; 1985.

9. Winters JC. Presurgical orthopedic in the surgical management of unilateral cleft lip and palate. Plastic Reconstr Surg J 1995; 95: 755-64.

10. Honda Y, Suzuki A. Longitudinal study on the changes of maxillary arch dimention in Japanese children with cleft lip or palate. Cleft Palate Craniofac J 1994;.32:2.

11. Mishima K, Mori $\mathrm{Y}$, Sugahara $\mathrm{T}$. Comparison between palatal configurations in UCLP infants with and without a hotz plate until four years of age. Cleft Palate Craniofac J 1999; 37: 185-90.

12. Pruzansky. Factor determining arch forming cleft lip and palate. Philadelphia: WB. Saunders Co.; 1965. 